\title{
Development and application of a next-generation- sequencing (NGS) approach to detect known and novel gene defects underlying retinal diseases
}

\author{
Isabelle Audo ${ }^{1,2,3,4,5^{*}}$, Kinga M Bujakowska, ${ }^{1,2,3}$, Thierry Léveillard ${ }^{1,2,3}$, Saddek Mohand-Saïd ${ }^{1,2,3,4}$, \\ Marie-Elise Lancelot ${ }^{1,2,3}$, Aurore Germain 1,2,3, Aline Antonio ${ }^{1,2,3,4}$, Christelle Michiels ${ }^{1,2,3}$, Jean-Paul Saraiva ${ }^{6}$, \\ Mélanie Letexier ${ }^{6}$, José-Alain Sahel ${ }^{1,2,3,4,7,8}$, Shomi S Bhattacharya ${ }^{1,2,3,5,9}$ and Christina Zeitz ${ }^{1,2,3^{*}}$
}

\begin{abstract}
Background: Inherited retinal disorders are clinically and genetically heterogeneous with more than 150 gene defects accounting for the diversity of disease phenotypes. So far, mutation detection was mainly performed by APEX technology and direct Sanger sequencing of known genes. However, these methods are time consuming, expensive and unable to provide a result if the patient carries a new gene mutation. In addition, multiplicity of phenotypes associated with the same gene defect may be overlooked.

Methods: To overcome these challenges, we designed an exon sequencing array to target 254 known and candidate genes using Agilent capture. Subsequently, 20 DNA samples from 17 different families, including four patients with known mutations were sequenced using Illumina Genome Analyzer IIx next-generation-sequencing (NGS) platform. Different filtering approaches were applied to identify the genetic defect. The most likely disease causing variants were analyzed by Sanger sequencing. Co-segregation and sequencing analysis of control samples validated the pathogenicity of the observed variants.

Results: The phenotype of the patients included retinitis pigmentosa, congenital stationary night blindness, Best disease, early-onset cone dystrophy and Stargardt disease. In three of four control samples with known genotypes NGS detected the expected mutations. Three known and five novel mutations were identified in NR2E3, PRPF3, EYS, PRPF8, CRB1, TRPM1 and CACNA1F. One of the control samples with a known genotype belongs to a family with two clinical phenotypes (Best and CSNB), where a novel mutation was identified for CSNB. In six families the disease associated mutations were not found, indicating that novel gene defects remain to be identified.

Conclusions: In summary, this unbiased and time-efficient NGS approach allowed mutation detection in 75\% of control cases and in 57\% of test cases. Furthermore, it has the possibility of associating known gene defects with novel phenotypes and mode of inheritance.
\end{abstract}

Keywords: NGS, retinal disorders, diagnostic tool.

\section{Background}

Inherited retinal disorders affect approximately 1 in 2000 individuals worldwide [1]. Symptoms and associated phenotypes are variable. In some groups the disease can be mild and stationary such as in congenital stationary night blindness (CSNB) or achromatopsia (ACHM), whereas other disorders are progressive leading to severe visual

\footnotetext{
* Correspondence: isabelle.audo@inserm.fr; christina.zeitz@inserm.fr 'INSERM, U968, Paris, F-75012, France

Full list of author information is available at the end of the article
}

impairment such as in rod-cone dystrophies, also known as retinitis pigmentosa (RP) or cone and cone-rod dystrophies. The heterogeneity of these diseases is reflected in the number of underlying gene defects. To date more than 150 genes have been implicated in different forms of retinal disorders http://www.sph.uth.tmc.edu/Retnet/home.htm and yet in a significant proportion of patients the disease causing mutation could not be identified, suggesting additional novel genes that remain to be discovered. Furthermore, recent studies have outlined that distinct phenotypes can 
be related to the dysfunction of the same gene [2-4]. Furthermore, there may be additional phenotype-genotype associations that are still not recognized. The state-of-theart phenotypic characterization including precise family history and functional as well as structural assessment (i.e. routine ophthalmic examination, perimetry, color vision, full field and multifocal electroretinography (ERG), fundus autofluorescence (FAF) imaging and optical coherence tomography (OCT)) allows targeted mutation analysis for some disorders. However, in most cases of inherited retinal diseases, similar phenotypic features can be due to a large number of different gene defects.

Various methods can be used for the identification of the corresponding genetic defect. All these methods have advantages and disadvantages. Sanger sequencing is still the gold-standard in determining the gene defect, but due to the heterogeneity of the disorders it is time consuming and expensive to screen all known genes. Mutation detection by commercially available APEX genotyping microarrays (ASPER Ophthalmics, Estonia) [5,6] allows the detection of only known mutations. In addition, a separate microarray has been designed for each inheritance pattern, which tends to escalate the costs especially in simplex cases, for which inheritance pattern cannot be predetermined. Indirect methods with single nucleotide polymorphism (SNP) microarrays for linkage and homozygosity mapping are also powerful tools, which has proven its reliability in identifying novel and known gene defects [7-12]. However, in case of homozygosity mapping the method can only be applied to consanguineous families or inbred populations. To overcome these challenges, we designed a custom sequencing array in collaboration with a company (IntegraGen, Evry, France) to target all exons and part of flanking sequences for 254 known and candidate retinal genes. This array was subsequently applied through NGS to a cohort of 20 patients from 17 families with different inheritance pattern and clinical diagnosis including RP, CSNB, Best disease, earlyonset cone dystrophy and Stargardt disease.

\section{Methods}

\section{Clinical investigation}

The study protocol adhered to the tenets of the Declaration of Helsinki and was approved by the local Ethics Committee (CPP, Ile de France V). Informed written consent was obtained from each study participant. Index patients underwent full ophthalmic examination as described before [13]. Whenever available, blood samples from affected and unaffected family members were collected for co-segregation analysis.

\section{Previous molecular genetic analysis}

Total genomic DNA was extracted from peripheral blood leucocytes according to manufacturer's recommendations
(Qiagen, Courtaboeuf, France). DNA samples from some patients with a diagnosis of RP were first analyzed and excluded for known mutations by applying commercially available microarray analysis (arRP and adRP ASPER Ophthalmics, Tartu, Estonia). In some cases, pathogenic variants in EYS, C2orf71, RHO, PRPF31, PRPH2 and RP1 were excluded by direct Sanger sequencing of the coding exonic and flanking intronic regions of the respective genes [13-17]. Conditions used to amplify PRPH2 can be provided on request.

\section{Molecular genetic analysis using NGS}

A custom-made SureSelect oligonucleotide probe library was designed to capture the exons of 254 genes for different retinal disorders and candidate genes according to Agilent's recommendations (Table 1). These genes include 177 known genes underlying retinal dysfunction (http://www.sph.uth.tmc.edu/retnet/sum-dis.htm, October 2010, Table 1) and 77 candidate genes associated with existing animal models and expression data (Table 2 ). The eArray web-based probe design tool was used for this purpose https://earray.chem.agilent.com/earray. The following parameters were chosen for probe design: 120 bp length, $3 \times$ probe-tiling frequency, 20 bp overlap in restricted regions, which were identified by the implementation of eArray's RepeatMasker program. A total of 27,430 probes, covering $1177 \mathrm{Mb}$, were designed and synthesized by Agilent Technologies (Santa Clara, CA, USA). Sequence capture, enrichment, and elution were performed according to the manufacturer's instructions (SureSelect, Agilent). Briefly, three $\mu \mathrm{g}$ of each genomic DNA were fragmented by sonication and purified to yield fragments of 150-200 bps. Paired-end adaptor oligonucleotides from Illumina were ligated on repaired DNA fragments, which were then purified and enriched by six PCR cycles. $500 \mathrm{ng}$ of the purified libraries were hybridized to the SureSelect oligo probe capture library for $24 \mathrm{~h}$. After hybridization, washing, and elution, the eluted fraction underwent 14 cycles of PCR-amplification. This was followed by purification and quantification by qPCR to obtain sufficient DNA template for downstream applications. Each eluted-enriched DNA sample was then sequenced on an Illumina GAIIx as paired-end 75 bp reads. Image analysis and base calling was performed using Illumina Real Time Analysis (RTA) Pipeline version 1.10 with default parameters. Sequence reads were aligned to the reference human genome (UCSC hg19) using commercially available software (CASAVA1.7, Illumina) and the ELANDv2 alignment algorithm. Sequence variation annotation was performed using the IntegraGen in-house pipeline, which consisted of gene annotation (RefSeq), detection of known polymorphisms (dbSNP 131, 1000 Genome) followed by mutation characterization (exonic, intronic, 
Table 1 Known retinal disease genes

\begin{tabular}{|c|c|}
\hline Number & Gene name \\
\hline 1 & $A B C A 4$ \\
\hline 2 & $A B C C 6$ \\
\hline 3 & ADAM9 \\
\hline 4 & AHI1 \\
\hline 5 & AIPL1 \\
\hline 6 & ALMS1 \\
\hline 7 & ARL6 \\
\hline 8 & ARMS2 \\
\hline 9 & ATXN7 \\
\hline 10 & BBS10 \\
\hline 11 & BBS12 \\
\hline 12 & BBS2 \\
\hline 13 & BBS4 \\
\hline 14 & BBS5 \\
\hline 15 & BBS7 \\
\hline 16 & BBS9 \\
\hline 17 & BEST1 \\
\hline 18 & C1QTNF5 \\
\hline 19 & C2 \\
\hline 20 & C2orf71 \\
\hline 21 & C3 \\
\hline 22 & CA4 \\
\hline 23 & CABP4 \\
\hline 24 & CACNA1F \\
\hline 25 & CACNA2D4 \\
\hline 26 & $C C 2 D 2 A$ \\
\hline 27 & $\mathrm{CDH} 23$ \\
\hline 28 & $\mathrm{CDH} 3$ \\
\hline 29 & CEP290 \\
\hline 30 & CERKL \\
\hline 31 & $C F B$ \\
\hline 32 & $\mathrm{CFH}$ \\
\hline 33 & CHM \\
\hline 34 & CLN3 \\
\hline 35 & CLRN1 \\
\hline 36 & CNGA1 \\
\hline 37 & CNGA3 \\
\hline 38 & CNGB1 \\
\hline 39 & CNGB3 \\
\hline 40 & CNNM4 \\
\hline 41 & COL11A1 \\
\hline 42 & COL2A1 \\
\hline 43 & COL9A1 \\
\hline 44 & CRB1 \\
\hline 45 & $C R X$ \\
\hline 46 & CYP4V2 \\
\hline 47 & DFNB31 \\
\hline
\end{tabular}

Table 1 Known retinal disease genes (Continued)

\begin{tabular}{|c|c|}
\hline 48 & $D M D$ \\
\hline 49 & DPP3 \\
\hline 50 & EFEMP1 \\
\hline 51 & ELOVL4 \\
\hline 52 & ERCC6 \\
\hline 53 & EYS \\
\hline 54 & FAM161A \\
\hline 55 & FBLN5 \\
\hline 56 & FSCN2 \\
\hline 57 & FZD4 \\
\hline 58 & GNAT1 \\
\hline 59 & GNAT2 \\
\hline 60 & GPR98 \\
\hline 61 & GRK1 \\
\hline 62 & GRM6 \\
\hline 63 & GUCA1A \\
\hline 64 & GUCA1B \\
\hline 65 & GUCY2D \\
\hline 66 & HMCN1 \\
\hline 67 & HTRA1 \\
\hline 68 & $I D H 3 B$ \\
\hline 69 & IMPDH1 \\
\hline 70 & IMPG2 \\
\hline 71 & INPP5E \\
\hline 72 & INVS \\
\hline 73 & IQCB1 \\
\hline 74 & $J A G 1$ \\
\hline 75 & KCNJ13 \\
\hline 76 & KCNV2 \\
\hline 77 & KLHL7 \\
\hline 78 & LCA5 \\
\hline 79 & LRAT \\
\hline 80 & LRP5 \\
\hline 81 & MERTK \\
\hline 82 & MFRP \\
\hline 83 & MKKS \\
\hline 84 & MKS1 \\
\hline 85 & MTND1 \\
\hline 86 & MTND6 \\
\hline 87 & $M T-A P 6$ \\
\hline 88 & MTND2 \\
\hline 89 & MTND5 \\
\hline 90 & MTND4 \\
\hline 91 & MYOTA \\
\hline 92 & $N D P$ \\
\hline 93 & NPHP1 \\
\hline 94 & NPHP3 \\
\hline 95 & NPHP4 \\
\hline
\end{tabular}


Table 1 Known retinal disease genes (Continued)

\begin{tabular}{|c|c|}
\hline 96 & NR2E3 \\
\hline 97 & $N R L$ \\
\hline 98 & $N Y X$ \\
\hline 99 & $O A T$ \\
\hline 100 & OFD1 \\
\hline 101 & OPA1 \\
\hline 102 & OPA3 \\
\hline 103 & OPN1LW \\
\hline 104 & OPN1MW \\
\hline 105 & OPN1SW \\
\hline 106 & OTX2 \\
\hline 107 & PANK2 \\
\hline 108 & PAX2 \\
\hline 109 & PCDH15 \\
\hline 110 & PCDH21 \\
\hline 111 & PDE6A \\
\hline 112 & PDE6B \\
\hline 113 & PDE6C \\
\hline 114 & PDE6G \\
\hline 115 & PDZD7 \\
\hline 116 & PEX1 \\
\hline 117 & PEX2 \\
\hline 118 & PEX7 \\
\hline 119 & PGK1 \\
\hline 120 & PHYH \\
\hline 121 & PITPNM3 \\
\hline 122 & $P R C D$ \\
\hline 123 & PROM1 \\
\hline 124 & PRPF3 \\
\hline 125 & PRPF31 \\
\hline 126 & PRPF8 \\
\hline 127 & PRPH2 \\
\hline 128 & $R A X 2$ \\
\hline 129 & $R B 1$ \\
\hline 130 & RBP3 \\
\hline 131 & RBP4 \\
\hline 132 & $R D 3$ \\
\hline 133 & RDH12 \\
\hline 134 & RDH5 \\
\hline 135 & $R G R$ \\
\hline 136 & RGS9 \\
\hline 137 & RGS9BP \\
\hline 138 & RHO \\
\hline 139 & RIMS1 \\
\hline 140 & RLBP1 \\
\hline 141 & ROM1 \\
\hline 142 & $R P 1$ \\
\hline
\end{tabular}

Table 1 Known retinal disease genes (Continued)

\begin{tabular}{|c|c|}
\hline 143 & RP1L1 \\
\hline 144 & $R P 2$ \\
\hline 145 & $R P 9$ \\
\hline 146 & RPE65 \\
\hline 147 & $R P G R$ \\
\hline 148 & RPGRIP1 \\
\hline 149 & RPGRIP1L \\
\hline 150 & RS1 \\
\hline 151 & SAG \\
\hline 152 & SDCCAG8 \\
\hline 153 & SEMA4A \\
\hline 154 & $S L C 24 A 1$ \\
\hline 155 & SNRNP200 \\
\hline 156 & SPATA7 \\
\hline 157 & TEAD1 \\
\hline 158 & TIMM8A \\
\hline 159 & TIMP3 \\
\hline 160 & TLR3 \\
\hline 161 & TLR4 \\
\hline 162 & TMEM126A \\
\hline 163 & TOPORS \\
\hline 164 & TREX1 \\
\hline 165 & TRIM32 \\
\hline 166 & TRPM1 \\
\hline 167 & TSPAN12 \\
\hline 168 & $\pi T C 8$ \\
\hline 169 & TTPA \\
\hline 170 & TULP1 \\
\hline 171 & UNC119 \\
\hline 172 & USH1C \\
\hline 173 & USH1G \\
\hline 174 & USH2A \\
\hline 175 & $V C A N$ \\
\hline 176 & WFS1 \\
\hline 177 & ZNF513 \\
\hline
\end{tabular}

silent, nonsense etc.). For each position, the exomic frequencies (homozygous and heterozygous) were determined from all the exomes already sequenced by IntegraGen and the exome results provided by HapMap project.

\section{Investigation of annotated sequencing data}

We received the annotated sequencing data in the form of excel tables. On average 946 SNPs and 83 insertions and deletions were identified for each sample (Figure 1). By using the filtering system, we first investigated variants (nonsense and missense mutations, intronic 
Table 2 Candidate genes for retinal disorders

\begin{tabular}{|c|c|c|c|}
\hline Number & Gene name & Reason & References \\
\hline 1 & $A D C Y 1$ & diff. Expression rd1 mouse & Chalmel et al., manuscript in preparatiom \\
\hline 2 & ANKRD33 & diff. Expression rd1 mouse & Chalmel et al., manuscript in preparatiom \\
\hline 3 & ANXA2 & Promotion of choroidal neovascularization & {$[36]$} \\
\hline 4 & $A R L 13 B$ & Cilia protein, mutations lead to Joubert Syndrome & {$[37]$} \\
\hline 5 & $B M P 7$ & Regulation of Pax 2 in mouse retina & {$[38]$} \\
\hline 6 & BSG & - & Thierry Leveillard personal commmunication \\
\hline 7 & CAMK2D & diff. Expression rd1 mouse & Chalmel et al., manuscript in preparatiom \\
\hline 8 & $C C D C 28 B$ & Modifier for BBS & {$[39,40]$} \\
\hline 9 & CLCN7 & Cln7-/- mice severe osteopetrosis and retinal degeneration & [41] \\
\hline 10 & COL4A3 & Alport syndrome, with eye abnormalities & {$[42,43]$} \\
\hline 11 & COL4A4 & Alport syndrome, with eye abnormalities & {$[42,44]$} \\
\hline 12 & COL4A5 & Alport syndrome, with eye abnormalities & {$[42,45]$} \\
\hline 13 & CUBN & - & Personal communication Renata Kozyraki \\
\hline 14 & CYP1B1 & glaucoma & {$[46]$} \\
\hline 15 & $\mathrm{DOHH}$ & diff. Expression rd1 mouse & Chalmel et al., manuscript in preparatiom \\
\hline 16 & DSCAML1 & diff. Expression rd1 mouse & Chalmel et al., manuscript in preparatiom \\
\hline 17 & ESRRB & diff. Expression rd1 mouse & Chalmel et al., manuscript in preparatiom \\
\hline 18 & $F I Z 1$ & Interactor of $N R L$ & [47] \\
\hline 19 & GJA9 & diff. Expression rd1 mouse & Chalmel et al., manuscript in preparatiom \\
\hline 20 & GNAZ & diff. Expression rd1 mouse & Chalmel et al., manuscript in preparatiom \\
\hline 21 & GNGT1 & diff. Expression rd1 mouse & Chalmel et al., manuscript in preparatiom \\
\hline 22 & GPR152 & diff. Expression rd1 mouse & Chalmel et al., manuscript in preparatiom \\
\hline 23 & HCN1 & diff. Expression rd1 mouse & Chalmel et al., manuscript in preparatiom \\
\hline 24 & HEATR5A & diff. Expression rd1 mouse & Chalmel et al., manuscript in preparatiom \\
\hline 25 & HIST1H1C & Expressed in retina & Expression databases \\
\hline 26 & IMPG1 & diff. Expression rd1 mouse & Chalmel et al., manuscript in preparatiom \\
\hline 27 & INSL5 & diff. Expression rd1 mouse & Chalmel et al., manuscript in preparatiom \\
\hline 28 & KCNB1 & diff. expression rd1 mouse & Chalmel et al., manuscript in preparatiom \\
\hline 29 & KCTD7 & Expressed in retina & Expression databases \\
\hline 30 & LASS4 & diff. expression rd1 mouse & Chalmel et al., manuscript in preparatiom \\
\hline 31 & LRIT2 & diff. expression rd1 mouse & Chalmel et al., manuscript in preparatiom Rd1 mouse \\
\hline 32 & LRP2 & - & Personal communication Renata Kozyraki \\
\hline 33 & MAB21L1 & diff. expression Rd1 mouse & Chalmel et al., manuscript in preparatiom \\
\hline 34 & MAP2 & diff. expression rd1 mouse & Chalmel et al., manuscript in preparatiom \\
\hline 35 & MAS1 & Degeneration of cones due to expression of Mas1 & [48] \\
\hline 36 & MAST2 & diff. expression rd1 mouse & Chalmel et al., manuscript in preparatiom \\
\hline 37 & MPP4 & diff. expression rd1 mouse & Chalmel et al., manuscript in preparatiom \\
\hline 38 & MYOC & glaucoma & [49] \\
\hline 39 & NDUFA12 & diff. expression rd1 mouse & Chalmel et al., manuscript in preparatiom \\
\hline 40 & NEUROD1 & BETA2/NeuroD1 -/- mouse: photoreceptor degeneration & [50] \\
\hline 41 & NOS2 & glaucoma & [51] \\
\hline 42 & NXNL1 & Rod-derived cone viability factor & {$[52]$} \\
\hline 43 & NXNL2 & Rod-derived cone viability factor 2 & [53] \\
\hline 44 & OPN1MW2 & Cone opsin, medium-wave-sensitive2 & [54] \\
\hline 45 & OPTN & glaucoma & [55] \\
\hline 46 & PFKFB2 & diff. expression rd1 mouse & Chalmel et al., manuscript in preparatiom \\
\hline 47 & PIAS3 & Rod photoreceptor development & {$[56]$} \\
\hline
\end{tabular}


Table 2 Candidate genes for retinal disorders (Continued)

\begin{tabular}{|c|c|c|c|}
\hline 48 & PKD2L1 & Diff. expression in human retinal detachment & Delyfer et al. 2011 submitted \\
\hline 49 & PLEKHA1 & Age-related macular degeneratiom & [57] \\
\hline 50 & PPEF2 & diff. expression rd1 mouse & Chalmel et al., manuscript in preparatiom \\
\hline 51 & $R A B 8 A$ & Interacts with RPGR, role in cilia biogenesis and maintenance & [58] \\
\hline 52 & RABGEF1 & diff. expression rd1 mouse & Chalmel et al., manuscript in preparatiom \\
\hline 53 & RCVRN & diff. expression rd1 mouse & Chalmel et al., manuscript in preparatiom \\
\hline 54 & RGS20 & diff. expression rd1 mouse & Chalmel et al., manuscript in preparatiom \\
\hline 55 & RNF144B & diff. expression rd1 mouse & Chalmel et al., manuscript in preparatiom \\
\hline 56 & $R O R B$ & Rod photoreceptor development in mice & [59] \\
\hline 57 & $R X R G$ & Retinoic acid receptor, highly expressed in the eye & Expression databases \\
\hline 58 & SGIP1 & diff. expression rd1 mouse & Chalmel et al., manuscript in preparatiom \\
\hline 59 & SLC16A8 & Altered visual function in ko-mice & [60] \\
\hline 60 & SLC17A7 & diff. expression rd1 mouse & Chalmel et al., manuscript in preparatiom \\
\hline 61 & STAM2 & diff. expression rd1 mouse & Chalmel et al., manuscript in preparatiom \\
\hline 62 & STK35 & diff. expression rd1 mouse & Chalmel et al., manuscript in preparatiom \\
\hline 63 & STX3 & diff. expression rd1 mouse & Chalmel et al., manuscript in preparatiom \\
\hline 64 & $S V 2 B$ & diff. expression rd1 mouse & Chalmel et al., manuscript in preparatiom \\
\hline 65 & $T B C 1 D 24$ & diff. expression rd1 mouse & Chalmel et al., manuscript in preparatiom \\
\hline 66 & THRB & Essential for M-cone development in rodents & [61] \\
\hline 67 & TMEM216 & Cilia protein, mutations lead to Joubert and Meckel syndrome & [62] \\
\hline 68 & TMEM67 & Cilia protein, mutations lead to Joubert & [63] \\
\hline 69 & TRPC1 & diff. expression rd1 mouse & diff. expression Rd1 mouse \\
\hline 70 & UHMK1 & diff. expression rd1 mouse & diff. expression Rd1 mouse \\
\hline 71 & VSX1 & Stimulator for promoter NXNL1 & [64] \\
\hline 72 & VSX2 & Stimulator for promoter NXNL1 & [64] \\
\hline 73 & WDR17 & diff. expression rd1 mouse & diff. expression Rd1 mouse \\
\hline 74 & WDR31 & diff. expression Nxnl1-/- mouse & [65] \\
\hline 75 & WISP1 & diff. expression rd1 mouse & Chalmel et al., manuscript in preparatiom \\
\hline 76 & XIAP & Protects photoreceptors in animal models of RP & {$[66]$} \\
\hline 77 & ZDHHC2 & diff. expression Rd1 mouse & Chalmel et al., manuscript in preparatiom \\
\hline
\end{tabular}

variants located $+/-5$ apart from exon), which were absent in dbSNP and NCBI databases http://ncbi.nlm. nih.gov/. In the absence of known gene defects or putative pathogenic variants (see below) in the first step, we selected known genes, which were previously clinically associated including variants present in dbSNP and NCBI databases (Figure 1). Each predicted pathogenic variant was confirmed by Sanger sequencing.

\section{Assessment of the pathogenicity of variants}

Following criteria were applied to evaluate the pathogenic nature of novel variations identified by NGS: 1) stop/frameshift variants were considered as most likely to be disease causing; 2) co-segregation in the family; 3) absence in control samples; 4) for missense mutations amino acid conservation was studied in the UCSC Genome Browser http://genome.ucsc.edu/ across species from all different evolutionary branches. If the amino acid residue did not change it was considered as "highly conserved". If a different change was seen in fewer than five species and not in the primates then it was considered as "moderately conserved" and if a change was present in 5-7, it was considered as "weakly conserved", otherwise the amino acid residue was considered as "not conserved", 5) pathogenicity predictions with bioinformatic tools (Polyphen: Polymorphism Phenotyping, http://genetics.bwh.harvard.edu/pph/ and SIFT: Sorting Intolerant From Tolerant, http://blocks.fhcrc.org/sift/ SIFT.html) if at least one of the program predicted the variant to be possibly damaging, it was considered to be pathogenic; 6) presence of the second mutant allele in the case of autosomal recessive inheritance. Mutations were described according to the HGVS website http:// www.hgvs.org/mutnomen. In accordance with this nomenclature, nucleotide numbering reflects cDNA numbering with +1 corresponding to the A of the ATG 


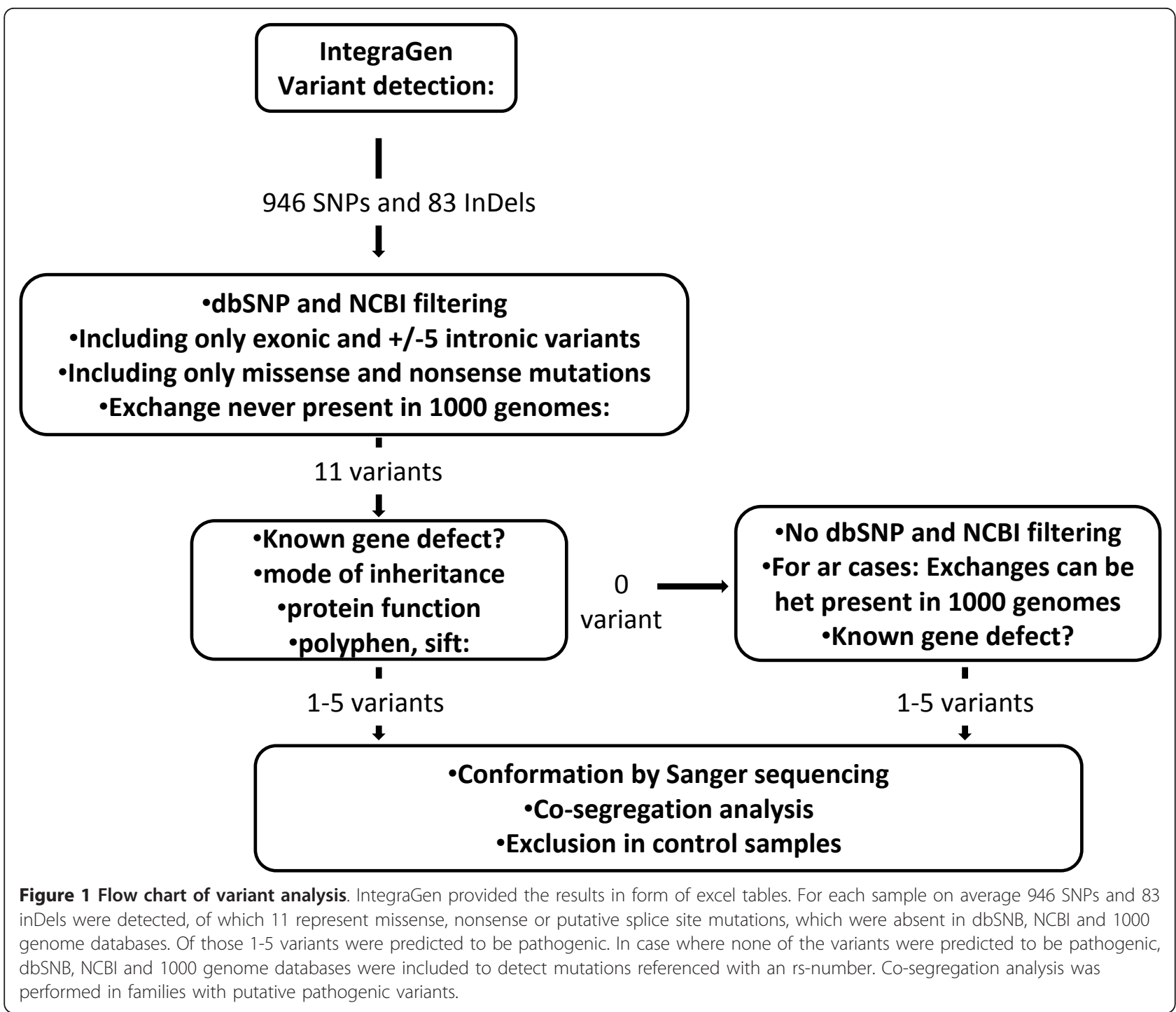

translation initiation codon in the reference sequence. The initiation codon is codon 1 . The correct nomenclature for mutation was checked applying Mutalyzer http://www.lovd.nl/mutalyzer/.

\section{Results}

The overall sequencing coverage of the captured regions was $98.4 \%$ and $90.4 \%$ for a $1 \times$ and a $10 \times$ coverage respectively. The overall sequencing depth was $>120 \times$. The number of reference and variant sequences detected by NGS, reflected the correct zygosity state of the variant; on average if $50 \%$ of the sequences represented the variant, then a heterozygous state was called, while if $100 \%$ of the sequences represented the variant, then a homozygous or hemizygous state was annotated by IntegraGen.
Validation of the novel genetic testing tool for retinal disorders

To validate the novel genetic testing tool for retinal disorders, we used four DNA samples from families, in which we had previously identified different types of mutations by Sanger sequencing: one 1 bp duplication and one 1 bp deletion in PRPF31 and missense mutations in TRPM1 and BEST1 (Table 3). Three of the four mutations were detectable by NGS, whereas the deletion in PRPF31 was not identified. To validate if this was due to a technical problem of deletion detection in general or low coverage at this position, the sequencing depth was investigated in detail. Indeed the coverage at this position reflected by the mean depth was only $\sim 1-6$ for all samples. This indicates that although the coverage in 
Table 3 Patients with known mutations used to validate the novel genetic approach for retinal disorders

\begin{tabular}{|c|c|c|c|c|c|c|c|c|}
\hline Index & Phenotype & Gene & Mutation & $\begin{array}{l}\text { Allele } \\
\text { State }\end{array}$ & $\begin{array}{l}\text { Read reference } \\
\text { NGS }\end{array}$ & $\begin{array}{l}\text { Read variant } \\
\text { NGS }\end{array}$ & $\begin{array}{l}\text { Mutation detected by } \\
\text { NGS }\end{array}$ & $\begin{array}{l}\text { Mean } \\
\text { depth }\end{array}$ \\
\hline $\begin{array}{l}\text { ClC00034, } \\
\text { F28 }\end{array}$ & adRP & PRPF31 & $\begin{array}{l}\text { c.666dup } \\
\text { p. } \\
\text { 1223YfsX56 }\end{array}$ & het & 11 & 13 & yes & $21.3-22.5$ \\
\hline $\begin{array}{l}\text { ClC00140, } \\
\text { F108 }\end{array}$ & adRP & PRPF31 & $\begin{array}{l}\text { c.997delG } \\
\text { p. } \\
\text { E333SfsX5 }\end{array}$ & het & - & - & no & $5.0-5.2$ \\
\hline $\begin{array}{l}\text { CIC00238, } \\
\text { F165 }\end{array}$ & $\operatorname{arCSNB}$ & TRPM1 & $\begin{array}{l}\text { C. } 1418 G> \\
\text { C } \\
\text { p.R473P }\end{array}$ & homo & 0 & 38 & yes & 36.7 \\
\hline $\begin{array}{l}\text { CIC00707, } \\
\text { F470 }\end{array}$ & $\begin{array}{l}\text { Best and adCSNB see } \\
\text { Table } 5\end{array}$ & BEST1 & $\begin{array}{l}\text { c.73C > T } \\
\text { p.R25W }\end{array}$ & het & 40 & 38 & yes & 99.4 \\
\hline
\end{tabular}

general was very good, specific probes used here need to be redesigned to improve the capture for specific exons.

\section{Detection of known and novel mutations}

Some of the patients from the 14 families with no known gene defect were previously excluded for known mutations using microarray analysis and by Sanger sequencing in the known genes EYS, C2orf71, RHO, PRPF31, PRPH2 and RP1. Other samples were never genetically investigated. In four DNA samples known mutations were detected (Table 4) from three different families with autosomal dominant (ad) or recessive (ar) RP. All mutations co-segregated with the phenotype (Figure 2). In seven samples, novel mutations in known genes were identified. These mutations co-segregated with the phenotype from five different families with adCSNB, $x$-linked incomplete CSNB, adRP, arRP and $x-$ linked RP (Table 5, Figures 3 and 4). One of the cases from these five families was also used as a control for Best disease carrying a known BEST1 mutation (Table 3 ). In addition to the Best phenotype, ERG-responses of this patient resembled those of complete CSNB, i.e. showing selective ON-bipolar pathway dysfunction. This phenotype was independent of the Best phenotype (Figure 3$)$. The most likely disease causing mutation detected by NGS was a novel heterozygous TRPM1 mutation (Table 4, Figure 3).

\section{Unsolved cases}

In six of the 14 families with Stargardt disease, adRP, adCD with postreceptoral defects, arRP, early onset arCD with macrocephaly and mental retardation described in affected sister and $x$-linked $\mathrm{CCSNB}$, the disease associated mutations remain to be elucidated or validated (Table 6, Figure 5).

\section{Discussion}

By using NGS in 254 known and candidate genes we were able to detect known and novel mutations in 57\% of families tested. In order to achieve this goal, we applied a rigorous protocol (Figure 1). To our knowledge, this is the first report using NGS to investigate all inherited retinal disorders at once. In a study restricted to adRP, Bowne and co-workers used a similar approach including 46 known and candidate genes for adRP [18]. All their cases had previously been screened and excluded for most of the known genes underlying adRP. The authors were able to identify known or novel mutations in five out of 21 cases in genes not included in a pre-screening [18]. This added five patients to their

Table 4 Detection of known mutations by using the novel genetic approach for retinal disorders

\begin{tabular}{|c|c|c|c|c|c|c|c|c|c|}
\hline Index & Phenotype & Pre-screening & Gene & Mutation & $\begin{array}{l}\text { Allele } \\
\text { State }\end{array}$ & $\begin{array}{l}\text { Read } \\
\text { reference } \\
\text { NGS }\end{array}$ & $\begin{array}{l}\text { Read } \\
\text { variant } \\
\text { NGS }\end{array}$ & Reference & $\begin{array}{l}\text { Mutation verified by } \\
\text { Sanger and co- } \\
\text { segregation }\end{array}$ \\
\hline $\begin{array}{l}\text { CIC00019, } \\
\text { F16 }\end{array}$ & adRP & $\begin{array}{l}\text { Linkage, } \mathrm{RHO}, \\
\text { PRPF31, PRPH2, } \\
\text { RP1 }\end{array}$ & PRPF3 & $\begin{array}{l}\text { c. } 1481 C>T \\
\text { p.T494M }\end{array}$ & het & 25 & 22 & [67] & yes \\
\hline $\begin{array}{l}\text { CIC0000893, } \\
\text { F574 }\end{array}$ & adRP & $\begin{array}{l}\text { RHO, PRPF31, } \\
P R P H 2, R P 1\end{array}$ & NR2E3 & $\begin{array}{l}\text { c.166G > A } \\
\text { p.G56R }\end{array}$ & het & 5 & 3 & [68] & yes \\
\hline $\begin{array}{l}\mathrm{CIC} 000128, \\
\text { F100 }\end{array}$ & $\begin{array}{l}\text { arRP, } \\
\text { consang. }\end{array}$ & - & EYS & $\begin{array}{l}\text { c.408_423del } \\
\text { p.N137VfsX24 }\end{array}$ & homo & - & 179 & {$[13,69]$} & yes \\
\hline $\begin{array}{l}\text { CIC0000943, } \\
\text { F100 }\end{array}$ & $\begin{array}{l}\text { arRP, } \\
\text { consang }\end{array}$ & - & EYS & $\begin{array}{l}\text { c.408_423del p. } \\
\text { N137VfsX24 }\end{array}$ & homo & 0 & 193 & {$[13,69]$} & yes \\
\hline
\end{tabular}




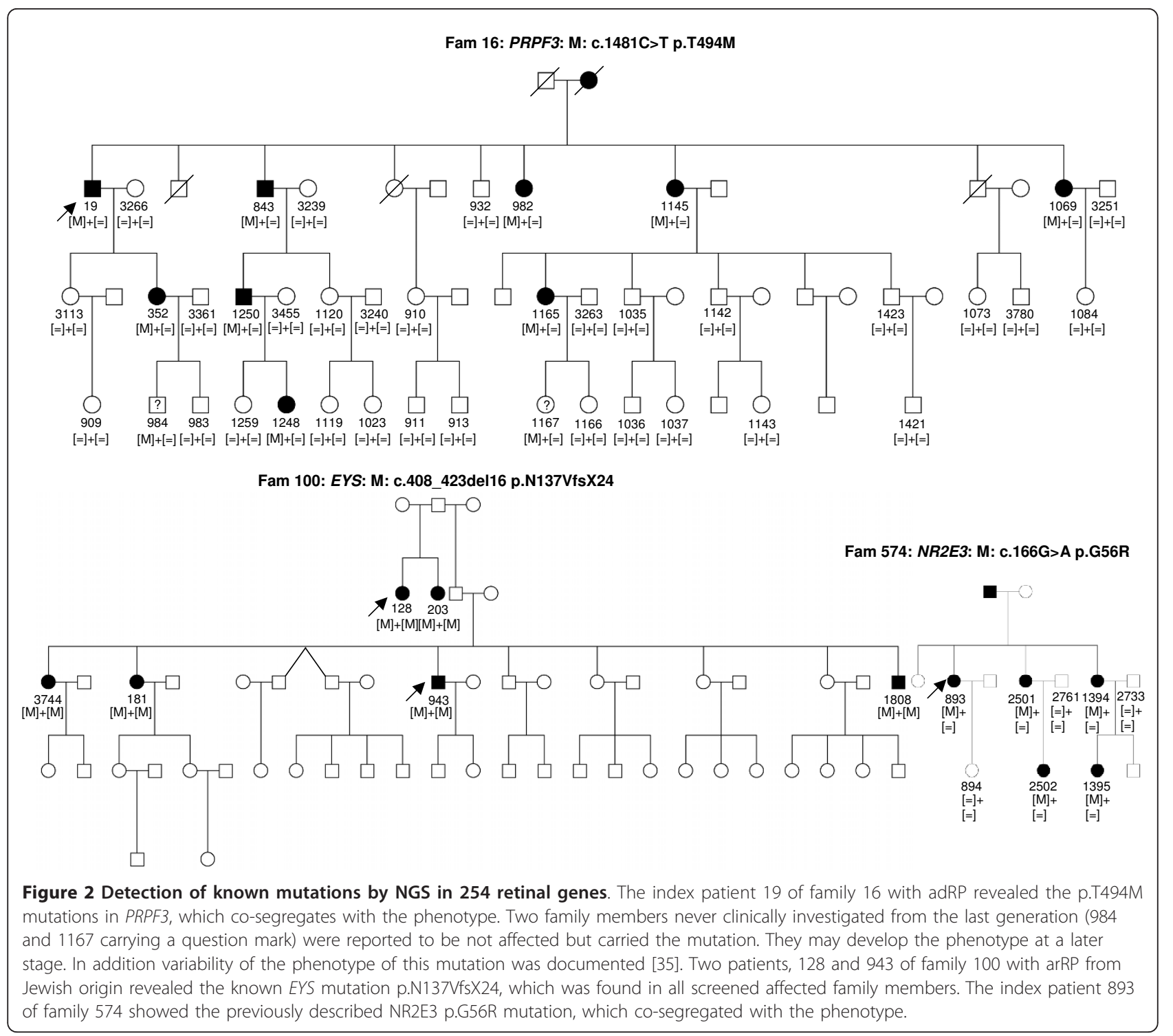

adRP cohort with known gene defects, indicating that $64 \%$ of their patients show known mutations with new genes still to be discovered in the remaining $36 \%$. The current study provides a more exhaustive tool, since it incorporates screening of 254 genes implicated in various retinal disorders of different inheritance patterns and additional candidate genes for these phenotypes. With this approach a cohort of both pre-screened and unscreened samples, was investigated. The mutation detection rate of $57 \%$ is high and was never obtained before by high throughput screening methods. Furthermore, this approach is probably less time consuming and expensive than existing methods such as direct sequencing of all known genes or microarray analysis. Of note however is one of the variants detected with the NGS approach (i.e. p.V973L exchange in GUCY2D), which was not confirmed by direct Sanger sequencing, suggesting the possibility of false positive using the high throughput screening. Verification by direct Sanger sequencing of most likely pathogenic variants is therefore essential to validate NGS data, although the false positive rate is assumed to be low (in our study $1 / 28$ verified sequence variants represented a false positive).

Overall, the study of 20 subjects from 17 families by NGS showed that most of the targeted regions are well covered (more than 98\%). However, some of the regions showed a lower coverage (GC-rich regions) or were not captured (repetitive regions). This was for instance the case for two genes underlying CCSNB, (i.e. NYX and GRM6) and the repetitive region of ORF15 of RPGR. For GC-rich regions the capture design could be improved in the future by modifying NGS chemistry, as 
Table 5 Detection of novel mutations by using the novel genetic approach for retinal disorders

\begin{tabular}{|c|c|c|c|c|c|c|c|c|c|c|c|}
\hline Index & Phenotype & $\begin{array}{l}\text { Pre- } \\
\text { screening }\end{array}$ & Gene & Mutation & $\begin{array}{l}\text { Allele } \\
\text { State }\end{array}$ & $\begin{array}{l}\text { Read } \\
\text { reference } \\
\text { NGS }\end{array}$ & $\begin{array}{l}\text { Read } \\
\text { variant } \\
\text { NGS }\end{array}$ & $\begin{array}{l}\text { Mutation } \\
\text { verified by } \\
\text { Sanger and } \\
\text { co- } \\
\text { segregation }\end{array}$ & Conservation & Polyphen & Sift \\
\hline $\begin{array}{l}\text { CIC00707, } \\
\text { F470 }\end{array}$ & $\begin{array}{l}\text { adCSNB } \\
\text { and Best } \\
\text { see Table } 3\end{array}$ & $\begin{array}{l}\text { RHO, } \\
\text { PDE6B, } \\
\text { GNAT1 }\end{array}$ & TRPM1 & $\begin{array}{l}\text { c. } 1961 \mathrm{~A} \\
>\mathrm{C} \\
\text { p.H654P }\end{array}$ & het & 39 & 38 & yes & $\begin{array}{l}\text { moderately } \\
\text { conserved }\end{array}$ & $\begin{array}{l}\text { possibly } \\
\text { damaging }\end{array}$ & tolerated \\
\hline $\begin{array}{l}\text { CIC000348, } \\
\text { F232 }\end{array}$ & adRP, mild & $\begin{array}{l}\text { RHO, } \\
\text { PRPF31, } \\
\text { PRPH2, } \\
\text { RP1, adRP } \\
\text { chip }\end{array}$ & PRPF8 & $\begin{array}{l}\text { c.6992A } \\
>\text { G } \\
\text { p. } \\
\text { E2331G }\end{array}$ & het & 13 & 10 & yes & $\begin{array}{l}\text { moderately } \\
\text { conserved }\end{array}$ & $\begin{array}{l}\text { possibly } \\
\text { damaging }\end{array}$ & $\begin{array}{l}\text { affect } \\
\text { protein } \\
\text { function }\end{array}$ \\
\hline $\begin{array}{l}\text { CIC000346, } \\
\text { F232 }\end{array}$ & adRP & - & PRPF8 & $\begin{array}{l}\text { c.6992A } \\
>\text { G } \\
\text { p.E2331G }\end{array}$ & het & 5 & 9 & yes & $\begin{array}{l}\text { moderately } \\
\text { conserved }\end{array}$ & $\begin{array}{l}\text { possibly } \\
\text { damaging }\end{array}$ & $\begin{array}{l}\text { affect } \\
\text { protein } \\
\text { function }\end{array}$ \\
\hline $\begin{array}{l}\text { CIC000347, } \\
\text { F232 }\end{array}$ & $\begin{array}{l}\text { as } \\
\text { adRP }\end{array}$ & - & PRPF8 & $\begin{array}{l}\text { c.6992A } \\
>\mathrm{G} \\
\text { p.E2331G }\end{array}$ & het & 15 & 17 & yes & $\begin{array}{l}\text { moderately } \\
\text { conserved }\end{array}$ & $\begin{array}{l}\text { possibly } \\
\text { damaging }\end{array}$ & $\begin{array}{l}\text { affect } \\
\text { protein } \\
\text { function }\end{array}$ \\
\hline $\begin{array}{l}\text { CIC04240, } \\
\text { F2025 }\end{array}$ & $\begin{array}{l}\text { arRP, } \\
\text { consang., } \\
\text { detailed } \\
\text { clinic in } \\
{[70]}\end{array}$ & $R S 1$ & CRB1 & $\begin{array}{l}\text { c. } 2219 \mathrm{C} \\
>\mathrm{T} \\
\text { p.S740F }\end{array}$ & homo & 2 & 194 & yes & $\begin{array}{l}\text { highly } \\
\text { conserved }\end{array}$ & $\begin{array}{l}\text { probably } \\
\text { damaging }\end{array}$ & $\begin{array}{l}\text { affect } \\
\text { protein } \\
\text { function }\end{array}$ \\
\hline $\begin{array}{l}\text { CIC00199, } \\
\text { F146 }\end{array}$ & $\begin{array}{l}\text { adRP or } x- \\
\text { linked RP } \\
\text { with } \\
\text { affected } \\
\text { carrier }\end{array}$ & $\begin{array}{l}\text { RHO, } \\
\text { PRPF31, } \\
\text { PRPH2, } \\
\text { RP1, adRP } \\
\text { chip }\end{array}$ & RPGR & $\begin{array}{l}\text { c.248-2A } \\
>\text { G } \\
\text { splice } \\
\text { defect }\end{array}$ & hetero & 30 & 22 & yes & $\begin{array}{l}\text { conserved } \\
\text { splice site }\end{array}$ & n.a. & n.a. \\
\hline $\begin{array}{l}\text { ClC04094, } \\
\text { F1915 }\end{array}$ & icCSNB & - & CACNA1F & $\begin{array}{l}\text { c.973C > } \\
T \\
\text { p.Q325X }\end{array}$ & hemi & 0 & 28 & yes & n.a. & n.a. & n.a. \\
\hline
\end{tabular}

it was successfully achieved for Sanger sequencing using different additives, which improved the amplification and subsequent sequencing. If repetitive regions like ORF15 of RPGR remain problematic for sequencing by NGS, direct Sanger sequencing of these targets might be the first screening of choice; in particular for disorders caused only by a few gene defects such as CSNB, and $\mathrm{xl-RP.}$

By applying NGS sequencing to our retinal panel, known and novel mutations were detected in different patients. We believe that our diagnostic tool is particularly important for heterogeneous disorders like RP, for which many gene defects with different prevalence have been associated to one phenotype. It also allows the rapid detection of novel mutations in minor genes which are often not screened as a priority by direct Sanger sequencing. This was the case in our study for three individuals from one family with adRP in which NGS detected a novel PRPF8 mutation in both affected and one unaffected family member (Table 4, Figure 4). In this family, the RP phenotype is mild and therefore it is possible that the unaffected member may develop symptoms later in life or alternatively it may be a case of incomplete penetrance as reported for another splicing factor gene, PRPF31 and recently for PRPF8 as well [19-22]. Interestingly, a novel TRPM1 mutation was identified in a patient with adCSNB, a gene previously only associated with arCSNB [23-26]. This is the first report of a TRPM1 mutation co-segregating with ad Schubert-Bornschein type complete CSNB. Since the location of this mutation is not different compared to other mutations leading to $\operatorname{arCSNB}$, it is not quite clear how TRPM1 mutations might lead to either ad or arCSNB. Functional investigations are needed to validate the pathogenicity of this variant. Furthermore, this finding suggests that TRPM1 heterozygous mutation carriers from arCSNB families should be investigated by electroretinography to determine whether they display similar retinal dysfunction as in affected members of the presented adCSNB family. Detection of a novel RPGR splice site mutation in family 146 presented a challenge. The actual disease causing change was concealed under a wrongly annotated rs62638633, which had previously been clinically associated to RP by a German group http://www.ncbi.nlm.nih.gov/sites/varvu?gen$\mathrm{e}=6103 \& \mathrm{rs}=62638633$, (personal communication, Markus Preising). These observations indicate that the stringent filtering we applied initially can mask those 


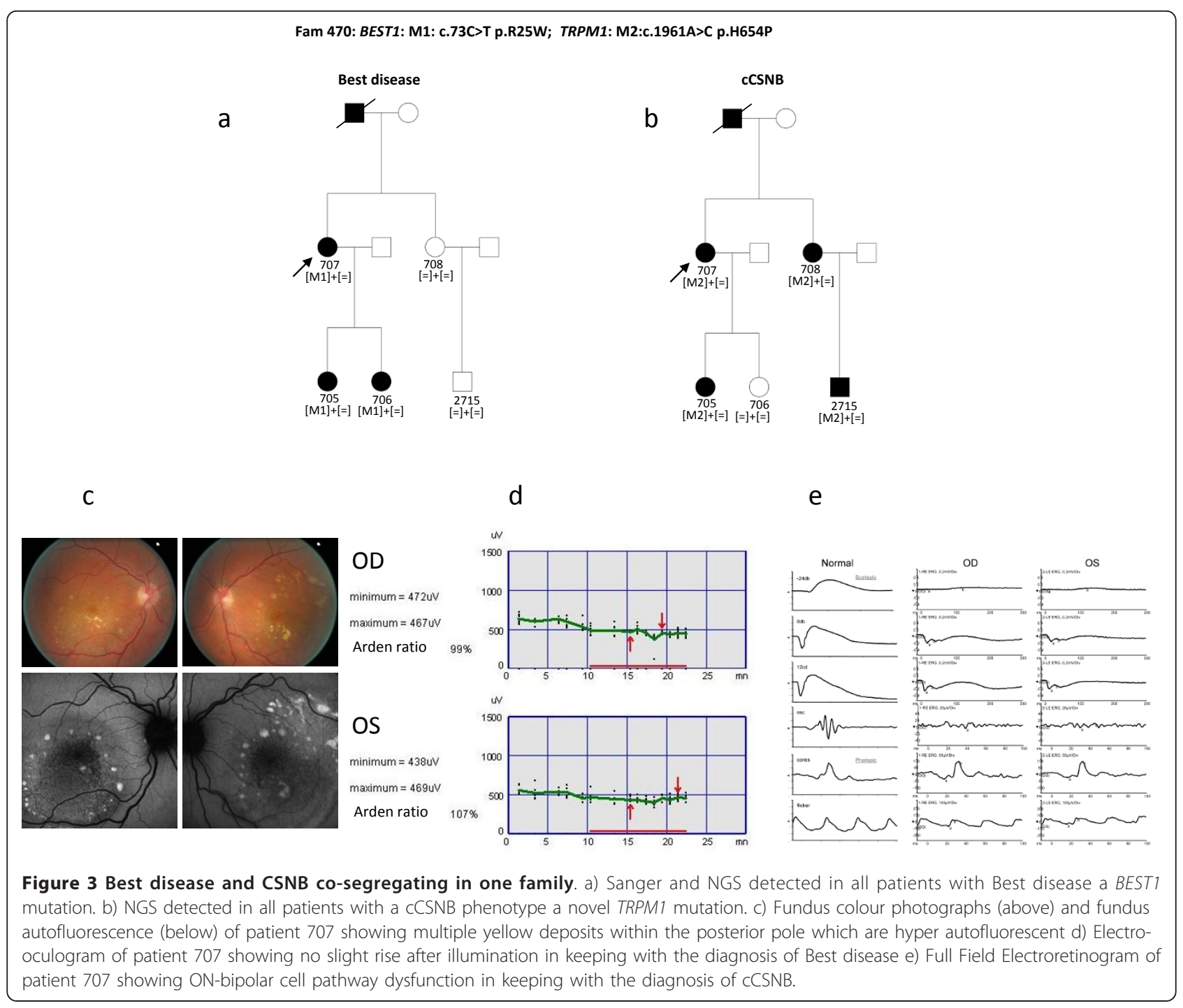

referenced disease causing variants. Bearing this in mind one can still first investigate unknown variants, but should then examine dbSNP for referenced variants either described to be disease causing, having a low minor allele frequency or present in interesting candidate genes. An accurate discrimination of non-pathogenic polymorphisms versus disease causing polymorphism in SNP databases is warranted to resolve this challenge.

In six families from the investigated cohort the disease causing mutations still remain to be identified. In the Stargardt patient with no pathogenic $A B C A 4$ mutations two variants in $C F H$ were detected, one of which (rs1061170) had previously been reported to predispose to age related macular degeneration (AMD) [27-29]. The second $C F H$ change is a novel variant, affecting a highly conserved residue, not found in NGS data from the other 19 samples and never associated with a disease. The variants co-segregated in the only available family members, which were the patient's parents. Apart from the association with AMD, CFH mutations have been previously associated with renal diseases, the most common being membranoproliferative glomerulonephritis and hemolytic uremic syndrome, which can be also associated with an eye phenotype [30,31]. No renal dysfunction was present in our patient. To validate if the two variants identified in $C F H$ are indeed disease causing, the DNA samples from other available family members for co-segregation analysis as well as characterization of functional consequences of the novel variant are needed. One patient with complete CSNB had an affected nephew and thus $\mathrm{x}$-linked inheritance was assumed. However, neither Sanger nor NGS detected a mutation in the only known $\mathrm{x}$-linked gene, $N Y X$, causing cCSNB. To exclude recessive inheritance TRPM1 and GRM6 were investigated in detail. Indeed the patient carried a novel heterozygous 

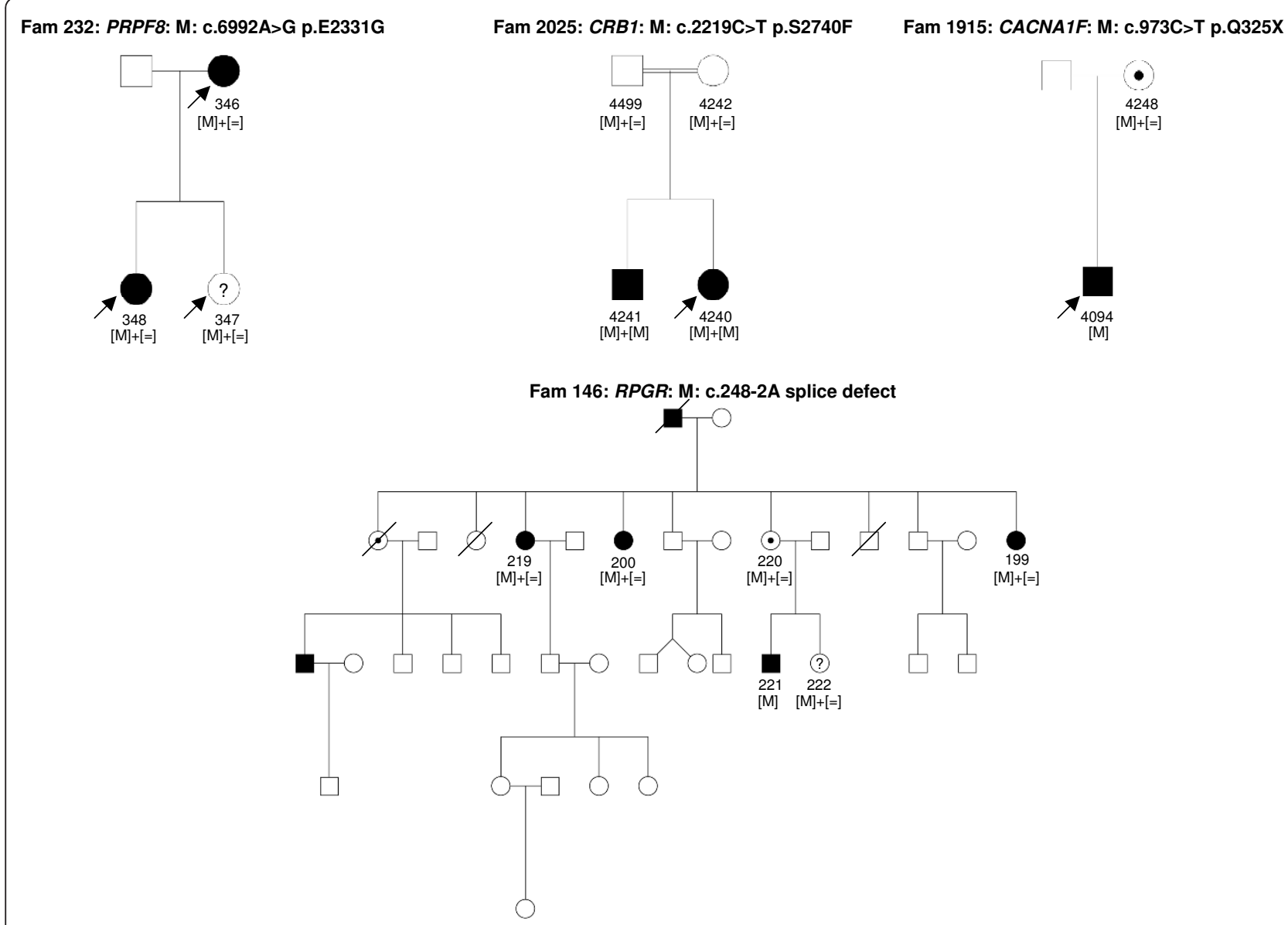

Figure 4 Detection of novel mutations using NGS in 254 retinal genes. Novel mutations in PRPF8, CRB1, RPGR and CACNA1F CO-segregated in affected and asymptomatic carriers with the adRP, arRP, $x$-linked dominant and X-liked icCSNB phenotypes respectively. Asymptomatic

individuals are marked with a question mark.

TRPM1 variant, which affects a highly conserved amino acid and was not identified in the other 19 samples investigated here (Table 6). However, direct Sanger sequencing of lower covered regions did not identify a second mutation in this gene. Similarly no mutations in GRM6 were identified. These findings outline the need for additional family members to determine, through co-segregation, the pathogenicity of the numerous variants identified by NGS. This was also true for two other families with nonsense mutations in CUBN (Fam795) and RP1L1 (Fam761) (Table 6). The nonsense mutation in $C U B N$, co-segregated with the phenotype in most of the family members (Figure 5). Had we not had access to additional family members, we might have retained this gene defect as the underlying cause for adCD and considered $C U B N$ as a new gene involved in adCD. None of the other putatively pathogenic mutations identified in CUBN, TRPM1 and GUCY2D co-segregated with the phenotype in this family (Table 6, Figure 5). RP1L1 was already a candidate for adRP [32] but was previously associated with occult macular dystrophy [33]. In our study, this variant did not co-segregate with the phenotype in other affected family members (data not shown).

This NGS study ended with six genetically unresolved families, which can be further investigated with whole exome sequencing. Although, no clear information about the actual percentage of missing gene defects underlying each group of inherited retinal disorders exists, previous studies have reported that in many cases the genetic cause still needs to be determined [18,34]. Whole exome sequencing approaches allow the detection of both, novel and known gene defects, but also generate numerous variants and therefore require the inclusion of more than one DNA sample for each family to rapidly exclude non-pathogenic variants. Due to the higher costs of exome sequencing for one sample compared to targeted sequencing, we propose to initially perform targeted sequencing in the index patient and proceed only after exclusion of a known gene defect to whole exome sequencing. 
Table 6 Patients with unsolved genotype and unlikely disease causing mutations

\begin{tabular}{|c|c|c|c|c|c|c|c|c|c|}
\hline Index & Phenotype & $\begin{array}{l}\text { Pre- } \\
\text { screening }\end{array}$ & Gene & Mutation & $\begin{array}{l}\text { Allele } \\
\text { State }\end{array}$ & $\begin{array}{l}\text { Read } \\
\text { reference } \\
\text { NGS }\end{array}$ & $\begin{array}{l}\text { Read } \\
\text { variant } \\
\text { NGS }\end{array}$ & $\begin{array}{l}\text { Mutation verified by } \\
\text { Sanger and co- } \\
\text { segregation }\end{array}$ & Comment \\
\hline \multirow[t]{4}{*}{$\begin{array}{l}\text { CIC03282, } \\
\text { F1388 }\end{array}$} & Stargardt & $\begin{array}{l}\text { ABCA4 } \\
\text { microarray }\end{array}$ & $A B C A 4$ & $\begin{array}{l}\text { c. } 1268 A>G \\
\text { p. } 1423 R\end{array}$ & het & 77 & 61 & yes & $\begin{array}{l}\text { but reported as } \\
\text { polymorphism } \\
\text { [71] }\end{array}$ \\
\hline & & & & $\begin{array}{l}\text { c.6764G > T } \\
\text { p.S2255I } \\
\text { no } \\
\text { additional } \\
\text { variants in } \\
\text { lower } \\
\text { covered } \\
\text { exons }\end{array}$ & het & 2 & 7 & yes & $\begin{array}{l}\text { but reported } \\
\text { as polymorphism } \\
\text { [72] }\end{array}$ \\
\hline & & & $\mathrm{CFH}$ & $\begin{array}{l}\text { c.3482C > A } \\
\text { p.P1161Q }\end{array}$ & het & 77 & 52 & yes & $\begin{array}{l}\text { conserved, } \\
\text { probably } \\
\text { damaging }\end{array}$ \\
\hline & & & & $\begin{array}{l}\text { c. } 1204 C>T \\
\text { p. } H 402 Y\end{array}$ & het & 94 & 87 & yes & AMD \\
\hline $\begin{array}{l}\text { CIC01269, } \\
\text { F761 }\end{array}$ & $\mathrm{adRP}$ & - & RP1L1 & $\begin{array}{l}\text { c. } 5959 C>T \\
\text { p.Q1987X }\end{array}$ & het & 145 & 150 & yes, did not co-segregate & $\begin{array}{l}\text { pass to whole } \\
\text { exome } \\
\text { sequencing }\end{array}$ \\
\hline \multirow[t]{4}{*}{$\begin{array}{l}\text { CIC01312, } \\
\text { F795 }\end{array}$} & $\begin{array}{l}\text { adCD with post- } \\
\text { receptoral defects }\end{array}$ & $\begin{array}{l}\text { RHO, } \\
\text { PDE6B, } \\
\text { GNAT1 } \\
\text { adRP chip }\end{array}$ & CUBN & $\begin{array}{l}\text { c. } 127 \mathrm{C}>\mathrm{T} \\
\text { p.R43X }\end{array}$ & het & 139 & 102 & yes, did not co-segregate & $\begin{array}{l}\text { pass to whole } \\
\text { exome } \\
\text { sequencing }\end{array}$ \\
\hline & & & CUBN & $\begin{array}{l}\text { c. } 9340 G>A \\
\text { p.G3114S }\end{array}$ & het & 61 & 44 & yes, did not co-segregate & \\
\hline & & & GUCY2D & $\begin{array}{l}\text { c. } 1499 \mathrm{C}>\mathrm{T} \\
\text { p.P500L }\end{array}$ & het & 41 & 34 & yes, did not co-segregate & \\
\hline & & & TRPM1 & $\begin{array}{l}\text { c. } 3904 \mathrm{~T}>\mathrm{C} \\
\text { p.C1302R }\end{array}$ & het & 102 & 99 & yes, did not co-segregate & \\
\hline \multirow[t]{5}{*}{$\begin{array}{l}\text { CIC03225, } \\
\text { F1362 }\end{array}$} & arRP consang. & arRP chip & PROM1 & $\begin{array}{l}\text { c.314A > G } \\
\text { p.Y105C }\end{array}$ & het & 120 & 115 & $\begin{array}{l}\text { yes, but no additional } \\
\text { mutation }\end{array}$ & $\begin{array}{l}\text { no homo, no } \\
\text { compound hets, } \\
\text { pass to whole } \\
\text { exome } \\
\text { sequencing }\end{array}$ \\
\hline & & & GUCY2D & $\begin{array}{l}\text { c.2917G > A } \\
\text { p.V973L }\end{array}$ & het & 6 & 2 & $\begin{array}{l}\text { false positive, not found } \\
\text { by Sanger }\end{array}$ & \\
\hline & & & DSCAML1 & $\begin{array}{l}\text { c. } 592 C>T \\
\text { p.R198C }\end{array}$ & het & 70 & 81 & $\begin{array}{l}\text { yes, but no additional } \\
\text { mutation }\end{array}$ & \\
\hline & & & TBC1D24 & $\begin{array}{l}\text { c.641G > A } \\
\text { p.R214H }\end{array}$ & het & 27 & 12 & $\begin{array}{l}\text { yes, but no additional } \\
\text { mutation }\end{array}$ & \\
\hline & & & TMEM67 & $\begin{array}{l}\text { c. } 1700 A>G \\
\text { p.Y567C }\end{array}$ & het & 80 & 58 & $\begin{array}{l}\text { yes, but no additional } \\
\text { mutation }\end{array}$ & \\
\hline \multirow[t]{3}{*}{$\begin{array}{l}\mathrm{ClC} 04757 \\
\mathrm{~F} 2364\end{array}$} & $\begin{array}{l}\text { Index and affected } \\
\text { sister early onset } \\
\text { arCD, macro- } \\
\text { cephaly and } \\
\text { mental retardation } \\
\text { in affected sister } \\
\text { consang. }\end{array}$ & - & IMPG2 & $\begin{array}{l}\text { c.3439C > T } \\
\text { p.P1147S }\end{array}$ & homo & 0 & 140 & no & $\begin{array}{l}\text { Polyphen and Sift } \\
\text { benign, not } \\
\text { conserved }\end{array}$ \\
\hline & & & PKD2L1 & $\begin{array}{l}\text { c. } 1027 C>T \\
\text { p.R343C }\end{array}$ & het & 63 & 68 & & \\
\hline & & & & $\begin{array}{l}\text { c. } 1202 T>G \\
\text { p.V401G }\end{array}$ & het & 25 & 19 & & $\begin{array}{l}\text { appeared also } \\
\text { het in } 11 \text { of our } \\
\text { samples } \\
\text { appeared also } \\
\text { het in affected } \\
\text { sister but no } \\
\text { other mutation in } \\
\text { less covered } \\
\text { exons }\end{array}$ \\
\hline
\end{tabular}


Table 6 Patients with unsolved genotype and unlikely disease causing mutations (Continued)

\begin{tabular}{|c|c|c|c|c|c|c|c|c|c|}
\hline & & & DFNB31 & $\begin{array}{l}\text { c. } 1943 \text { C > A } \\
\text { p. } 5648 Y\end{array}$ & het & 7 & 7 & yes & $\begin{array}{l}\text { affected sister } \\
\text { also both variants } \\
\text { but both come } \\
\text { from father, no } \\
\text { other variant in } \\
\text { lower covered } \\
\text { region. }\end{array}$ \\
\hline & & & & $\begin{array}{l}\text { c. } 2644 C>A \\
\text { p.R882S }\end{array}$ & het & 27 & 14 & yes & \\
\hline & & & EYS & $\begin{array}{l}\text { c.7597A > G } \\
\text { p.K2533E }\end{array}$ & het & 151 & 149 & yes & $\begin{array}{l}\text { Affected sister } \\
\text { does not carry } \\
\text { this variant }\end{array}$ \\
\hline & & & RPGRIP1 & $\begin{array}{l}\text { c.2417C > T } \\
\text { p.T806I }\end{array}$ & het & 138 & 132 & no & not conserved \\
\hline $\begin{array}{l}\text { CIC04152, } \\
\text { F1955 }\end{array}$ & $\begin{array}{l}\text { male } x \text {-linked } \\
\text { cCSNB, has } \\
\text { affected nephew }\end{array}$ & NYX & TRPM1 & $\begin{array}{l}\text { c. } 470 C>T \\
\text { p.S157F }\end{array}$ & het & 118 & 130 & $\begin{array}{l}\text { yes, no other het } \\
\text { mutation. }\end{array}$ & $\begin{array}{l}\text { x-linked } \\
\text { inheritance and } \\
\text { phenotype } \\
\text { verification }\end{array}$ \\
\hline
\end{tabular}

Index patients and respective gene defect are highlighted in bold. In some cases also family members were used for NGS.

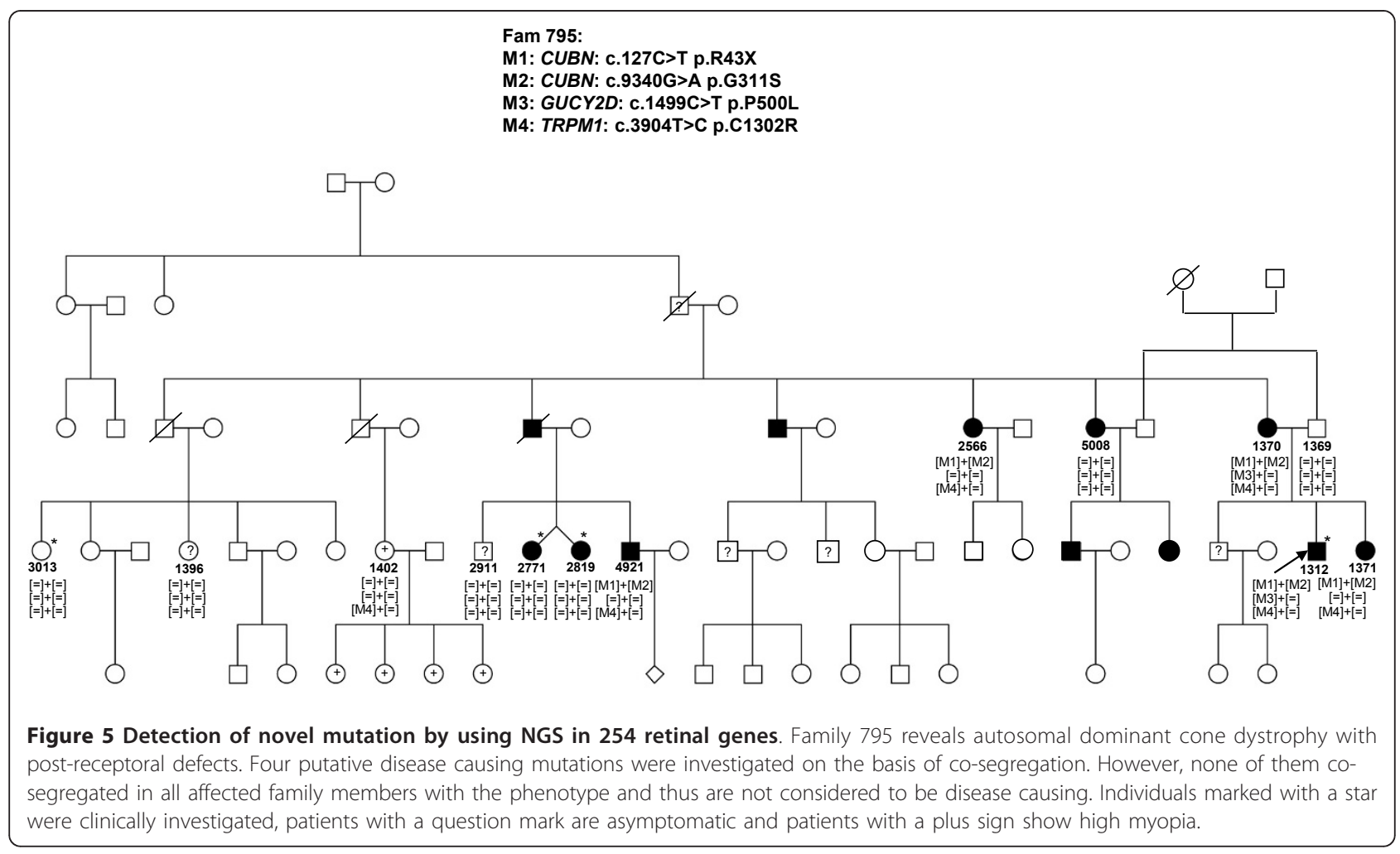

\section{Conclusions}

In summary, our diagnostic tool is an unbiased time efficient method, which not only allows detecting known and novel mutations in known genes but also potentially associates known gene defects with novel phenotypes. This genetic testing tool can now be applied to large cohorts of inherited retinal disorders and should rapidly deliver the prevalence of known genes and the percentage of cases with missing genetic defect for underlying forms of retinal disorders.

\section{List of abbreviations}

ad: autosomal dominant; ar: autosomal recessive; as: asymptomatic; het: heterozygous; homo: homozygous; hemi: hemizygous; - not noted; consang.: 
consanguinity was reported; n.a.: not applicable; CSNB: congenital stationary night blindness; RP: retinitis pigmentosa:

\section{Acknowledgements}

The authors are grateful to the families described in this study, Dominique Santiard-Baron and Christine Chaumeil for their help in DNA collection and to clinical staff. The project was financially supported by GIS-maladies rares (CZ), Agence Nationale de la Recherche (ANR, SSB), Foundation Voir et Entendre and BQR, Foundation Fighting Blindness (IA, FFB Grant \# CD-CL0808-0466-CHNO and the CIC503 recognized as an FFB center, FFB Grant \# C-CMM-0907-0428-INSERM04), Ville de Paris and region Ile de France.

\section{Author details}

${ }^{1}$ INSERM, U968, Paris, F-75012, France. ${ }^{2}$ CNRS, UMR_7210, Paris, F-75012 France. ${ }^{3}$ UPMC Univ Paris 06, UMR_S 968, Department of Genetics, Institut de la Vision, Paris, F-75012, France. ${ }^{4}$ Centre Hospitalier National d'Ophtalmologie des Quinze-Vingts, INSERM-DHOS CIC 503, Paris, F-75012, France. ${ }^{5}$ UCL-Institute of Ophthalmology, London, UK. ${ }^{6}$ ntegraGen SA, Genopole CAMPUS 1 bat G8 FR-91030 EVRY France. ${ }^{7}$ Fondation Ophtalmologique Adolphe de Rothschild, Paris, France. ${ }^{8}$ Académie des Sciences-Institut de France, 75006 Paris, France. ${ }^{9}$ Department of Celular Therapy and Regenerative Medicine, Andalusian Molecular Biology and Regenerative Medicine Centre (CABIMER), Isla de Cartuja, Seville, Spain.

\section{Authors' contributions}

IA was involved in the study design, participated in the choice of genes, interpreted the NGS data, clinically investigated patients, collected DNA samples, and has been involved in drafting the manuscript. KB participated in the choice of genes, interpreted the NGS data and has been involved in drafting the manuscript. TL was involved in the study design, participated in the choice of genes and has been involved in drafting the manuscript. SM-S clinically investigated patients and collected DNA samples. M-EL confirmed the NGS data by Sanger sequencing, performed control and co-segregation analysis. AG extracted DNA, confirmed the NGS data by Sanger sequencing, and performed control and co-segregation analysis. AA extracted DNA, confirmed the NGS data by Sanger sequencing, and performed control and co-segregation analysis. CM confirmed the NGS data by Sanger sequencing, and performed control and co-segregation analysis. J-PS performed NGS. ML performed the bioinformatic interpretation of NGS. J-AS clinically investigated patients and participated in the study design. SSB participated in the study design and has been involved in drafting the manuscript. CZ has made the study design, participated in the choice of genes, interpreted the NGS data and wrote the manuscript. All authors read and approved the final manuscript.

\section{Competing interests}

The authors declare that they have no competing interests.

Received: 12 September 2011 Accepted: 25 January 2012

Published: 25 January 2012

\section{References}

1. Sohocki MM, Daiger SP, Bowne SJ, Rodriquez JA, Northrup H, Heckenlively JR, Birch DG, Mintz-Hittner H, Ruiz RS, Lewis RA, Saperstein DA, Sullivan LS: Prevalence of mutations causing retinitis pigmentosa and other inherited retinopathies. Hum Mutat 2001, 17:42-51.

2. Boon CJ, den Hollander Al, Hoyng CB, Cremers FP, Klevering BJ, Keunen JE: The spectrum of retinal dystrophies caused by mutations in the peripherin/RDS gene. Prog Retin Eye Res 2008, 27:213-235.

3. Boon CJ, Klevering BJ, Leroy BP, Hoyng CB, Keunen JE, den Hollander Al: The spectrum of ocular phenotypes caused by mutations in the BEST1 gene. Prog Retin Eye Res 2009, 28:187-205.

4. Schorderet DF, Escher P: NR2E3 mutations in enhanced S-cone sensitivity syndrome (ESCS), Goldmann-Favre syndrome (GFS), clumped pigmentary retinal degeneration (CPRD), and retinitis pigmentosa (RP). Hum Mutat 2009, 30:1475-1485.

5. Jaakson K, Zernant J, Kulm M, Hutchinson A, Tonisson N, Glavac D, RavnikGlavac M, Hawlina M, Meltzer MR, Caruso RC, Testa F, Maugeri A, Hoyng CB, Gouras $P$, Simonelli $F$, Lewis RA, Lupski JR, Cremers FP, Allikmets R: Genotyping microarray (gene chip) for the $A B C R$ (ABCA4) gene. Hum Mutat 2003, 22:395-403.
6. Zeitz C, Labs S, Lorenz B, Forster U, Uksti J, Kroes HY, De Baere E, Leroy BP, Cremers FP, Wittmer M, van Genderen MM, Sahel JA, Audo I, Poloschek CM, Mohand-Said S, Fleischhauer JC, Huffmeier U, Moskova-Doumanova V, Levin AV, Hamel CP, Leifert D, Munier FL, Schorderet DF, Zrenner $E_{\text {, }}$ Friedburg C, Wissinger B, Kohl S, Berger W: Genotyping microarray for CSNB-associated genes. Invest Ophthalmol Vis Sci 2009, 50:5919-5926.

7. Wang $H$, den Hollander Al, Moayedi Y, Abulimiti A, Li Y, Collin RW, Hoyng CB, Lopez I, Bray M, Lewis RA, Lupski JR, Mardon G, Koenekoop RK, Chen R: Mutations in SPATA7 cause leber congenital amaurosis and juvenile retinitis pigmentosa. Am J Hum Genet 2009, 84:380-387.

8. den Hollander Al, McGee TL, Ziviello C, Banfi S, Dryja TP, GonzalezFernandez F, Ghosh D, Berson EL: A homozygous missense mutation in the IRBP gene (RBP3) associated with autosomal recessive retinitis pigmentosa. Invest Ophthalmol Vis Sci 2009, 50:1864-1872.

9. Collin RW, Littink KW, Klevering BJ, van den Born LI, Koenekoop RK, Zonneveld MN, Blokland EA, Strom TM, Hoyng CB, den Hollander Al, Cremers FP: Identification of a $2 \mathrm{Mb}$ human ortholog of Drosophila eyes shut/spacemaker that is mutated in patients with retinitis pigmentosa. Am J Hum Genet 2008, 83:594-603.

10. Collin RW, Safieh C, Littink KW, Shalev SA, Garzozi HJ, Rizel L, Abbasi AH, Cremers FP, den Hollander Al, Klevering BJ, Ben-Yosef T: Mutations in C2ORF71 cause autosomal-recessive retinitis pigmentosa. Am J Hum Genet 2010, 86:783-788.

11. Bandah-Rozenfeld D, Collin RW, Banin E, van den Born LI, Coene KL, Siemiatkowska AM, Zelinger L, Khan MI, Lefeber DJ, Erdinest I, Testa F, Simonelli F, Voesenek K, Blokland EA, Strom TM, Klaver CC, Qamar R, Banfi S, Cremers FP, Sharon D, den Hollander Al: Mutations in IMPG2, encoding interphotoreceptor matrix proteoglycan 2, cause autosomalrecessive retinitis pigmentosa. Am J Hum Genet 2010, 87:199-208.

12. Audo I, Bujakowska K, Mohand-Said S, Tronche S, Lancelot ME, Antonio A, Germain A, Lonjou C, Carpentier W, Sahel JA, Bhattacharya S, Zeitz C: A novel DFNB31 mutation associated with Usher type 2 syndrome showing variable degrees of auditory loss in a consanguineous Portuguese family. Mol Vis 2011, 17:1598-1606.

13. Audo I, Sahel JA, Mohand-Said S, Lancelot ME, Antonio A, MoskovaDoumanova V, Nandrot EF, Doumanov J, Barragan I, Antinolo G, Bhattacharya SS, Zeitz C: EYS is a major gene for rod-cone dystrophies in France. Hum Mutat 2010, 31:E1406-1435.

14. Audo I, Lancelot ME, Mohand-Said S, Antonio A, Germain A, Sahel JA, Bhattacharya SS, Zeitz C: Novel C2orf71 mutations account for approximately $1 \%$ of cases in a large French arRP cohort. Hum Mutat 2011, 32:E2091-2103.

15. Audo I, Manes G, Mohand-Said S, Friedrich A, Lancelot ME, Antonio A Moskova-Doumanova V, Poch O, Zanlonghi X, Hamel CP, Sahel JA, Bhattacharya SS, Zeitz C: Spectrum of rhodopsin mutations in French autosomal dominant rod-cone dystrophy patients. Invest Ophthalmol Vis Sci 2010, 51:3687-3700.

16. Audo I, Bujakowska K, Mohand-Said S, Lancelot ME, Moskova-Doumanova V, Waseem NH, Antonio A, Sahel JA, Bhattacharya SS, Zeitz C: Prevalence and novelty of PRPF31 mutations in French autosomal dominant rod-cone dystrophy patients and a review of published reports. BMC Med Genet 2010, 11:145.

17. Audo I, Mohand-Said S, Dhaenens CM, Germain A, Orhan E, Antonio A, Hamel C, Sahel JA, Bhattacharya SS, Zeitz C: RP1 and autosomal dominant rod-cone dystrophy: Novel mutations, a review of published variants, and genotype-phenotype correlation. Hum Mutat 2012, 33:73-80.

18. Bowne SJ, Sullivan LS, Koboldt DC, Ding L, Fulton R, Abbott RM, Sodergren EJ, Birch DG, Wheaton DH, Heckenlively JR, Liu Q, Pierce EA, Weinstock GM, Daiger SP: Identification of disease-causing mutations in autosomal dominant retinitis pigmentosa (adRP) using next-generation DNA sequencing. Invest Ophthalmol Vis Sci 2011, 52:494-503.

19. Vithana EN, Abu-Safieh L, Pelosini L, Winchester E, Hornan D, Bird AC, Hunt DM, Bustin SA, Bhattacharya SS: Expression of PRPF31 mRNA in patients with autosomal dominant retinitis pigmentosa: a molecular clue for incomplete penetrance? Invest Ophthalmol Vis Sci 2003, 44:4204-4209.

20. McGee TL, Devoto M, Ott J, Berson EL, Dryja TP: Evidence that the penetrance of mutations at the RP11 locus causing dominant retinitis pigmentosa is influenced by a gene linked to the homologous RP11 allele. Am J Hum Genet 1997, 61:1059-1066.

21. Vithana EN, Abu-Safieh L, Allen MJ, Carey A, Papaioannou M, Chakarova C, Al-Maghtheh M, Ebenezer ND, Willis C, Moore AT, Bird AC, Hunt DM, 
Bhattacharya SS: A human homolog of yeast pre-mRNA splicing gene, PRP31, underlies autosomal dominant retinitis pigmentosa on chromosome 19q13.4 (RP11). Mol Cell 2001, 8:375-381.

22. Maubaret CG, Vaclavik V, Mukhopadhyay R, Waseem NH, Churchill A, Holder GE, Moore AT, Bhattacharya SS, Webster AR: Autosomal Dominant Retinitis Pigmentosa with Intrafamilial Variability and Incomplete Penetrance in Two Families carrying Mutations in PRPF8. Invest Ophthalmol Vis Sci 2011.

23. Li Z, Sergouniotis PI, Michaelides M, Mackay DS, Wright GA, Devery S, Moore AT, Holder GE, Robson AG, Webster AR: Recessive mutations of the gene TRPM1 abrogate ON bipolar cell function and cause complete congenital stationary night blindness in humans. Am J Hum Genet 2009 85:711-719.

24. van Genderen MM, Bijveld MM, Claassen YB, Florijn RJ, Pearring JN, Meire FM, McCall MA, Riemslag FC, Gregg RG, Bergen AA, Kamermans M: Mutations in TRPM1 are a common cause of complete congenital stationary night blindness. Am J Hum Genet 2009, 85:730-736.

25. Audo I, Kohl S, Leroy BP, Munier FL, Guillonneau X, Mohand-Said S, Bujakowska K, Nandrot EF, Lorenz B, Preising M, Kellner U, Renner AB, Bernd A, Antonio A, Moskova-Doumanova V, Lancelot ME, Poloschek CM, Drumare I, Defoort-Dhellemmes S, Wissinger B, Leveillard T, Hamel CP, Schorderet DF, De Baere E, Berger W, Jacobson SG, Zrenner E, Sahel JA, Bhattacharya SS, Zeitz C: TRPM1 is mutated in patients with autosomalrecessive complete congenital stationary night blindness. Am J Hum Genet 2009, 85:720-729.

26. Nakamura M, Sanuki R, Yasuma TR, Onishi A, Nishiguchi KM, Koike C, Kadowaki M, Kondo M, Miyake $\mathrm{Y}$, Furukawa T: TRPM1 mutations are associated with the complete form of congenital stationary night blindness. Mol Vis 2010, 16:425-437.

27. Klein RJ, Zeiss C, Chew EY, Tsai JY, Sackler RS, Haynes C, Henning AK, SanGiovanni JP, Mane SM, Mayne ST, Bracken MB, Ferris FL, Ott J, Barnstable $\mathrm{C}$, Hoh J: Complement factor $\mathrm{H}$ polymorphism in age-related macular degeneration. Science 2005, 308:385-389.

28. Edwards AO, Ritter R, Abel KJ, Manning A, Panhuysen C, Farrer LA: Complement factor $\mathrm{H}$ polymorphism and age-related macular degeneration. Science 2005, 308:421-424.

29. Haines JL, Hauser MA, Schmidt S, Scott WK, Olson LM, Gallins P, Spencer KL, Kwan SY, Noureddine M, Gilbert JR, Schnetz-Boutaud N, Agarwal A, Postel EA, Pericak-Vance MA: Complement factor $\mathrm{H}$ variant increases the risk of age-related macular degeneration. Science 2005, 308:419-421.

30. Ault BH: Factor $\mathrm{H}$ and the pathogenesis of renal diseases. Pediatr Nephrol 2000, 14:1045-1053.

31. Boon CJ, van de Kar NC, Klevering BJ, Keunen JE, Cremers FP, Klaver CC, Hoyng CB, Daha MR, den Hollander Al: The spectrum of phenotypes caused by variants in the CFH gene. Mol Immunol 2009, 46:1573-1594.

32. Bowne SJ, Daiger SP, Malone KA, Heckenlively JR, Kennan A, Humphries $P$, Hughbanks-Wheaton D, Birch DG, Liu Q, Pierce EA, Zuo J, Huang Q, Donovan DD, Sullivan LS: Characterization of RP1L1, a highly polymorphic paralog of the retinitis pigmentosa 1 (RP1) gene. Mol Vis 2003, 9:129-137.

33. Akahori M, Tsunoda K, Miyake $Y$, Fukuda $Y$, Ishiura H, Tsuji S, Usui T, Hatase T, Nakamura M, Ohde H, Itabashi T, Okamoto H, Takada Y, Iwata T: Dominant mutations in RP1L1 are responsible for occult macular dystrophy. Am J Hum Genet 2010, 87:424-429.

34. Berger W, Kloeckener-Gruissem B, Neidhardt J: The molecular basis of human retinal and vitreoretinal diseases. Prog Retin Eye Res 2010, 29:335-375.

35. Vaclavik V, Gaillard MC, Tiab L, Schorderet DF, Munier FL: Variable phenotypic expressivity in a Swiss family with autosomal dominant retinitis pigmentosa due to a T494M mutation in the PRPF3 gene. Mol Vis 2010, 16:467-475

36. Zhao SH, Pan DY, Zhang Y, Wu JH, Liu X, Xu Y: Annexin A2 promotes choroidal neovascularization by increasing vascular endothelial growth factor expression in a rat model of argon laser coagulation-induced choroidal neovascularization. Chin Med J (Engl) 2010, 123:713-721.

37. Cantagrel V, Silhavy JL, Bielas SL, Swistun D, Marsh SE, Bertrand JY, Audollent S, Attie-Bitach T, Holden KR, Dobyns WB, Traver D, Al-Gazali L, Ali BR, Lindner TH, Caspary T, Otto EA, Hildebrandt F, Glass IA, Logan CV, Johnson CA, Bennett C, Brancati F, Valente EM, Woods CG, Gleeson JG: Mutations in the cilia gene ARL13B lead to the classical form of Joubert syndrome. Am J Hum Genet 2008, 83:170-179.
38. Sehgal R, Sheibani N, Rhodes SJ, Belecky Adams TL: BMP7 and SHH regulate $P a x 2$ in mouse retinal astrocytes by relieving TLX repression. Dev Biol 2009, 332:429-443.

39. Beales PL, Badano JL, Ross AJ, Ansley SJ, Hoskins BE, Kirsten B, Mein CA Froguel P, Scambler PJ, Lewis RA, Lupski JR, Katsanis N: Genetic interaction of BBS1 mutations with alleles at other BBS loci can result in nonMendelian Bardet-Biedl syndrome. Am J Hum Genet 2003, 72:1187-1199.

40. Badano JL, Leitch CC, Ansley SJ, May-Simera H, Lawson S, Lewis RA, Beales PL, Dietz HC, Fisher S, Katsanis N: Dissection of epistasis in oligogenic Bardet-Biedl syndrome. Nature 2006, 439:326-330.

41. Kornak U, Kasper D, Bosl MR, Kaiser E, Schweizer M, Schulz A, Friedrich W, Delling $\mathrm{G}$, Jentsch TJ: Loss of the CIC-7 chloride channel leads to osteopetrosis in mice and man. Cell 2001, 104:205-215.

42. Colville DJ, Savige J: Alport syndrome. A review of the ocular manifestations. Ophthalmic Genet 1997, 18:161-173.

43. Lemmink $H H$, Mochizuki $T$, van den Heuvel $L P$, Schroder $C H$, Barrientos $A$ Monnens LA, van Oost BA, Brunner HG, Reeders ST, Smeets HJ: Mutations in the type IV collagen alpha 3 (COL4A3) gene in autosomal recessive Alport syndrome. Hum Mol Genet 1994, 3:1269-1273.

44. Jefferson JA, Lemmink HH, Hughes AE, Hill CM, Smeets HJ, Doherty CC, Maxwell AP: Autosomal dominant Alport syndrome linked to the type IV collage alpha 3 and alpha 4 genes (COL4A3 and COL4A4). Nephrol Dial Transplant 1997, 12:1595-1599.

45. Lemmink HH, Kluijtmans LA, Brunner HG, Schroder $\mathrm{CH}$, Knebelmann $\mathrm{B}$, Jelinkova $E$, van Oost BA, Monnens LA, Smeets $H J$ : Aberrant splicing of the COL4A5 gene in patients with Alport syndrome. Hum Mol Genet 1994, 3:317-322

46. Stoilov I, Akarsu AN, Sarfarazi M: Identification of three different truncating mutations in cytochrome P4501B1 (CYP1B1) as the principal cause of primary congenital glaucoma (Buphthalmos) in families linked to the GLC3A locus on chromosome 2p21. Hum Mol Genet 1997, 6:641-647

47. Mitton KP, Swain PK, Khanna H, Dowd M, Apel IJ, Swaroop A: Interaction of retinal bZIP transcription factor NRL with Flt3-interacting zinc-finger protein Fiz1: possible role of Fiz1 as a transcriptional repressor. Hum Mol Genet 2003, 12:365-373.

48. Xu X, Quiambao AB, Roveri L, Pardue MT, Marx JL, Rohlich P, Peachey NS, Al-Ubaidi MR: Degeneration of cone photoreceptors induced by expression of the Mas1 protooncogene. Exp Neurol 2000, 163:207-219.

49. Kubota R, Kudoh J, Mashima Y, Asakawa S, Minoshima S, Hejtmancik JF, Oguchi $Y$, Shimizu N: Genomic organization of the human myocilin gene (MYOC) responsible for primary open angle glaucoma (GLC1A). Biochem Biophys Res Commun 1998, 242:396-400.

50. Pennesi ME, Cho JH, Yang Z, Wu SH, Zhang J, Wu SM, Tsai MJ: BETA2/ NeuroD1 null mice: a new model for transcription factor-dependent photoreceptor degeneration. J Neurosci 2003, 23:453-461.

51. Liu B, Neufeld AH: Expression of nitric oxide synthase-2 (NOS-2) in reactive astrocytes of the human glaucomatous optic nerve head. Glia 2000, 30:178-186.

52. Leveillard T, Mohand-Said S, Lorentz O, Hicks D, Fintz AC, Clerin E, Simonutti M, Forster V, Cavusoglu N, Chalmel F, Dolle P, Poch O, Lambrou G, Sahel JA: Identification and characterization of rod-derived cone viability factor. Nat Genet 2004, 36:755-759.

53. Chalmel F, Leveillard T, Jaillard C, Lardenois A, Berdugo N, Morel E, Koehl P, Lambrou G, Holmgren A, Sahel JA, Poch O: Rod-derived Cone Viability Factor-2 is a novel bifunctional-thioredoxin-like protein with therapeutic potential. BMC Mol Biol 2007, 8:74.

54. Tsutsumi M, Ikeyama K, Denda S, Nakanishi J, Fuziwara S, Aoki H, Denda M: Expressions of rod and cone photoreceptor-like proteins in human epidermis. Exp Dermatol 2009, 18:567-570.

55. Rezaie T, Child A, Hitchings R, Brice G, Miller L, Coca-Prados M, Heon E, Krupin T, Ritch R, Kreutzer D, Crick RP, Sarfarazi M: Adult-onset primary open-angle glaucoma caused by mutations in optineurin. Science 2002, 295:1077-1079.

56. Onishi A, Peng GH, Hsu C, Alexis U, Chen S, Blackshaw S: Pias3-dependent SUMOylation directs rod photoreceptor development. Neuron 2009, 61:234-246.

57. Montezuma SR, Sobrin L, Seddon JM: Review of genetics in age related macular degeneration. Semin Ophthalmol 2007, 22:229-240.

58. Murga-Zamalloa CA, Atkins SJ, Peranen J, Swaroop A, Khanna H: Interaction of retinitis pigmentosa GTPase regulator (RPGR) with RAB8A GTPase: 
implications for cilia dysfunction and photoreceptor degeneration. Hum Mol Genet 2010, 19:3591-3598.

59. Jia L, Oh EC, Ng L, Srinivas M, Brooks M, Swaroop A, Forrest D: Retinoidrelated orphan nuclear receptor RORbeta is an early-acting factor in rod photoreceptor development. Proc Natl Acad Sci USA 2009, 106:17534-17539.

60. Daniele LL, Sauer B, Gallagher SM, Pugh EN Jr, Philp NJ: Altered visual function in monocarboxylate transporter 3 (Slc16a8) knockout mice. Am J Physiol Cell Physiol 2008, 295:C451-457.

61. Ng L, Hurley JB, Dierks B, Srinivas M, Salto C, Vennstrom B, Reh TA, Forrest $\mathrm{D}: \mathrm{A}$ thyroid hormone receptor that is required for the development of green cone photoreceptors. Nat Genet 2001, 27:94-98

62. Valente EM, Logan CV, Mougou-Zerelli S, Lee JH, Silhavy JL, Brancati F, Iannicelli M, Travaglini L, Romani S, Illi B, Adams M, Szymanska K, Mazzotta A, Lee JE, Tolentino JC, Swistun D, Salpietro CD, Fede C, Gabriel S, Russ C, Cibulskis K, Sougnez C, Hildebrandt F, Otto EA, Held S, Diplas BH, Davis EE, Mikula M, Strom CM, Ben-Zeev B, et al: Mutations in TMEM216 perturb ciliogenesis and cause Joubert, Meckel and related syndromes. Nat Genet 2010, 42:619-625.

63. Baala L, Romano S, Khaddour R, Saunier S, Smith UM, Audollent S, Ozilou C, Faivre L, Laurent N, Foliguet B, Munnich A, Lyonnet S, Salomon R, EnchaRazavi F, Gubler MC, Boddaert N, de Lonlay P, Johnson CA, Vekemans M, Antignac C, Attie-Bitach T: The Meckel-Gruber syndrome gene, MKS3, is mutated in Joubert syndrome. Am J Hum Genet 2007, 80:186-194.

64. Reichman S, Kalathur RK, Lambard S, Ait-Ali N, Yang Y, Lardenois A, Ripp R, Poch O, Zack DJ, Sahel JA, Leveillard T: The homeobox gene CHX10/NSX2 regulates RdCVF promoter activity in the inner retina. Hum Mol Genet 2010, 19:250-261.

65. Cronin T, Raffelsberger W, Lee-Rivera I, Jaillard C, Niepon ML, Kinzel B, Clerin E, Petrosian A, Picaud S, Poch O, Sahel JA, Leveillard T: The disruption of the rod-derived cone viability gene leads to photoreceptor dysfunction and susceptibility to oxidative stress. Cell Death Differ 2010, 17:1199-1210.

66. Leonard KC, Petrin D, Coupland SG, Baker AN, Leonard BC, LaCasse EC, Hauswirth WW, Korneluk RG, Tsilfidis C: XIAP protection of photoreceptors in animal models of retinitis pigmentosa. PLOS ONE 2007, 2:e314.

67. Chakarova CF, Hims MM, Bolz H, Abu-Safieh L, Patel RJ, Papaioannou MG, Inglehearn CF, Keen TJ, Willis C, Moore AT, Rosenberg T, Webster AR, Bird AC, Gal A, Hunt D, Vithana EN, Bhattacharya SS: Mutations in HPRP3, a third member of pre-mRNA splicing factor genes, implicated in autosomal dominant retinitis pigmentosa. Hum Mol Genet 2002, 11:87-92.

68. Coppieters F, Leroy BP, Beysen D, Hellemans J, De Bosscher K, Haegeman G, Robberecht K, Wuyts W, Coucke PJ, De Baere E: Recurrent mutation in the first zinc finger of the orphan nuclear receptor NR2E3 causes autosomal dominant retinitis pigmentosa. Am J Hum Genet 2007, 81:147-157.

69. Bandah-Rozenfeld D, Littink KW, Ben-Yosef T, Strom TM, Chowers I, Collin RW, den Hollander Al, van den Born LI, Zonneveld MN, Merin S, Banin E, Cremers FP, Sharon D: Novel null mutations in the EYS gene are a frequent cause of autosomal recessive retinitis pigmentosa in the Israeli population. Invest Ophthalmol Vis Sci 2010, 51:4387-4394.

70. Bujakowska K, Audo I, Mohand-Said S, Lancelot ME, Antonio A, Germain A, Leveillard T, Letexier M, Saraiva JP, Lonjou C, Carpentier W, Sahel JA, Bhattacharya SS, Zeitz C: CRB1 mutations in inherited retinal dystrophies. Hum Mutat 2011, , 33: 306-315.

71. Rivera A, White K, Stohr H, Steiner K, Hemmrich N, Grimm T, Jurklies B, Lorenz B, Scholl HP, Apfelstedt-Sylla E, Weber BH: A comprehensive survey of sequence variation in the ABCA4 (ABCR) gene in Stargardt disease and age-related macular degeneration. Am J Hum Genet 2000, 67:800-813.

72. Shroyer NF, Lewis RA, Lupski JR: Analysis of the ABCR (ABCA4) gene in 4aminoquinoline retinopathy: is retinal toxicity by chloroquine and hydroxychloroquine related to Stargardt disease? Am J Ophthalmol 2001, 131:761-766.

doi:10.1186/1750-1172-7-8

Cite this article as: Audo et al.: Development and application of a nextgeneration-sequencing (NGS) approach to detect known and novel gene defects underlying retinal diseases. Orphanet Journal of Rare Diseases 2012 7:8.

\section{Submit your next manuscript to BioMed Central and take full advantage of:}

- Convenient online submission

- Thorough peer review

- No space constraints or color figure charges

- Immediate publication on acceptance

- Inclusion in PubMed, CAS, Scopus and Google Scholar

- Research which is freely available for redistribution

Submit your manuscript at www.biomedcentral.com/submit
Biomed Central 